\title{
The Specifies of Using Technologies of Analyzing Situations for Active Education of Specialists in Customs Service in the Russian Federation and Foreign Countries
}

\author{
Denis Korovyakovsky \\ The Customs Right and the Organization of Customs Affairs Department \\ Russian University of Transport \\ Moscow, Russia \\ E-mail: sirah13@mail.ru
}

\begin{abstract}
The article focuses on the problems of training specialists in the customs service, based on analyzing technologies in situations with active student's education (listeners). The author considers in detail the principles, forms and methods of interactive education and analyses their application in Russia and abroad (using the example of Universities). Also the author circumstantially describes the use of training-imitation complexes for specialists' preparation in the customs service. In the end of the article the author comes to the decision that with the using of situation analysis during the specialists training in this area, students have an opportunity in additional competences development.
\end{abstract}

Keywords-customs service; education; higher education; interactive education; training; active methods of studying

\section{INTRODUCTION}

The problem of informative action activation, independence and creative skills development of students is still one of the most vital in special disciplines research of students' education plan of specialization 38.05.02 "Customs service" in the Russian Federation [1]. The direction of education to the competences formation as the readiness and human ability for socialization presumes didactic and psychological conditions creation, in which a student can show not just intellectual and informative activity, but a personal social position too, an individuality, which allows to express yourself as the subject of education.

The principles of interactive education:

- Communication inside a dialog;

- Work in small groups using communication;

- Role-active (playing) activity;

- Training education organization.

- The forms and methods of interactive education in customs service can be classified in a following way:
- Discussion: a dialog, a group discussion, a situation analysis from the practice, an analysis of situations of a moral choice, etc.;

- Playing: didactic and creative plays, including business (administration) plays, role plays, organizing- activity plays;

- Training forms of studies leading (communication trainings, trainings of sensitivity), which can include discussions and playing methods of education.

Wherein the priority place is occupied by active methods of education. In the aspect of customs service specialist training the active methods of education are those methods which are different because of future customs service specialists activities in education process [2]. These education methods allow to realize their intellectualinformative and creative activity in professional-directive practical problems solution.

\section{THE NECESSARY PROFESSIONAL COMPETENCES DURING CUSTOMS SERVICE SPECIALIST TRAINING TRAINING COMPLEXES}

One of the forming direction of required professional competences in the customs service specialization is the use of interactive methods of education. Nowadays the leading Universities of Russia that realize the specialization "Customs service" actively apply the training and playing methods of education, being realized in special automatic system frames: educational trainings and stands. The complex training system consists of two types of trainings [3].

\section{A. Training-imitation Complexes}

Training-imitation complexes, which model and reproduce situations during customs service operations and procedures, close to real conditions and forming the 
recommendations of acting in certain situations. Such systems train students in following modes:

- Studying the execution of customs service documents;

- The following working of scenarios execution of service duties in typical customs service situations;

- A complex work in customs service subdivision;

In general complexes are being developed by the tutors of specific sections (topics) of the education courses for students, which means that they include the complex of exercises (problems) about the topics of the section and explanatory (studying) material for the exercises (problems).

\section{B. Adaptive Automatic Training}

Adaptive automatic trainings are directed to research, acquiring and perfection of practical skills of working with program - informative instruments of the uniform automatic information system during the process of education and professional preparation of customs service specialists.

Due to the complex of educational exercises and situations, included to training-imitation KTS, the following opportunities appear:

- To create problem situations

- To determine any necessary parameters (in a certain problem, situation).

One of the factors, which makes better theoretical and practical students level, is the using of playing system technology in the process of discipline developing. To make the examination of the developing level of discipline content assimilation, the formation of competences allow business plays as the innovative educational method with the using of special program security. The essence of the playing modelling method with the using of electronic trainings is the imitation of many professional plots, situations and episodes, which need decisions. For making these decisions it is necessary to make:

- The analysis of the situation for detection and formulating the problem;

- The structure of the problems and setting goals;

- Its decision with simulator using.

Because nowadays main working processes of customs service are being realized by a big complex of automatic systems, information-calculating systems, program goals and a whole line of separate problems, future customs service specialist needs to have skills of working in automatic systems, being used in custom practice.

\section{THE ANALYSIS OF FOREIGN PRACTICE OF USING INTERACTIVE FORMS OF EDUCATION FOR CUSTOMS SERVICE SPECIALISTS' TRAINING}

In foreign universities are also being used interactive methods of customs service workers education, for example employees should make the 18 -week training with special program in the Federal Centre of specialists training of the law enforcement agencies in Brunswick, Georgia, when they are being admitted to the work [4].

As the preparation program is complex it includes ways and methods of education of detecting fair trade, a criminalistics basis course, handling of weapons education, an anti-terror preparation, a studying of giving the first help for suffers. Besides the program includes the preparation in intercultural association, effective communications, the studying of making interviews and interrogation techniques and the preparation for a few other subjects and skills, which form the qualification in combination in customs service joint. Along with that in Redjis University it can be given skills in criminal face profiling through online-criminalistics programs and a bachelor's degree of criminalistics science and Master of Science in Criminology. Making courses promotes better professional specialists' potential in customs service, allows to analyze social, politic and ecological factors, which lead to crime and research the key views to the criminal behavior [5].

During last two decades many decisions which were suggested and introduced in customs service were technological. They include scanners, international bases data bases and many camera systems for activity monitoring. As with any skill which develops during time non-verbal communication reading needs training and continuous practice to maximize the ability of a customer not just to detect the signal, but to react adequately to minimize threats. Uniting the non-verbal behavior education, double-linguistic signals and emotional face detecting, customers and border security employees will be much more skillful in correct interpreting of people emotions they see during their work [6].

Custom and border service in USA introduced the system of face detecting in Dallas airport in the 2015. Larry Panetta from the service explained the advantages of face detecting in the exhibition Border Security Expo: "Face detecting is the way we work for" - she said in the conference. "In present time we have photos of everybody, so we don't need to make any lists" [7].

The center of custom and excise studying (CCES) in Australia (Canberra) is the world leading provider of training and education of narrow specified areas of customs, excise and border administration [8]. The center of custom and excise studying works in partnership with Australian University, which gives additional opportunities to students to consolidate their skills in custom administration, border administration and adjacent areas. In Australia modern technologies of face detecting are based on algorithms of machine studying (the system SmartGate) [9]. These algorithms analyze digital images, which find function combinations, which are unique for the considering face. The last result is mathematical representation, which allows to compare the face quickly and clearly.

Along with that in Russia gradually introduces profile education for employees. The first term "profiling" was used in the context of formation a searching psychological portrait (profile) of the suspect, following the steps in the crime 
scene. In such a way the Ural's customers studied with that special method, made by psychologists. The method reflects in the example of the certain situation: the group of students arrived from New York City. About 20 people came through the customs service control. A half of the students have forbidden products in accompanied luggage. The profilers as customs service employees, who had the special education, should detect these people. They look for everything: mimic, gestures, clothes, sight and passengers hands moving [10].

In Russia in the June of the 2016 was made the qualification training for listeners of additional professional program «The methods and technologies of detecting contraventions of custom legislation demands based on the analysis of passengers' behavior (profiling) in one of the Universities, which realize the specialization "Customs service". The realization of the program was made firstly, and listeners high appreciated the relevance of given knowledge and for their professional activity.

\section{CONCLUSION}

In perspective the practical-directed trainings can be introduced, with the help of which administrative employees of the customs services can master their skills.

The above said examples reflect the application in the teaching process of the technology of analyzing situations for active studying a customs service specialist. The specify of this technology is that during making studies in the form of situation exercise projected results can be reached. Nevertheless it can be reached only with communication to other participants, making complex connected calculations, listening to different points of view and arguing personal position. The situations analyzing technology for active education include following positions:

- The analysis of certain situations;

- The method of situations education - case-study, the method of cases, method of the 'incident';

- The method of critical precedents analysis, the method of roles ignoring, playing projecting.

- The following aims of situation analyzing technology demonstration:

- The development of analyzing skills and critical thinking;

- The harmony of theory and practice;

- The presentation of examples of made decisions and their effects;

- The demonstration of different positions and points of view;

- The formation of skills of alternative versions assessment in conditions of uncertainly.

- Except these aims for using situations analysis are being formed the following metacompetences:
- Communication skills development-the pure expression of thoughts, the ability of listening to the others, to express argued position, to select counter argumentation, etc.;

- Presentation skills development and skills of information presentation;

- Self-confidence and confidence in one's strength appearance;

- Strong skills of rational behavior acquirement under the lack of information for complex problems decisions;

- Interactive skills formation, which allow effectively communicate in a group and make collective decisions;

- Expert skills acquire;

- Self-evaluation forms and consequently the changing of individual style of communication and behavior;

- Partnerships' establishment and acquirement of communication skills;

- Skills of finding necessary knowledge and decisionmaking in a problem, assimilation of algorithms of administration decisions;

- The motivation for education changes - students get highly interested in studies.

Besides, during the situation analysis students begin to acquire competitiveness, personal and collective responsibility, personal values and settings change, skills of reputation administration and a positive style of life.

\section{REFERENCES}

[1] The Order of the Ministry of Defense of the Russian Federation as of 17.08.2015 № 850 "On the Statement of the Federal State Educational Standard of Higher Education in Specialization 38.05.02 of the Customs service (specialist level)" (Registered in the Ministry of Justice of the Russian Federation as of 09.09.2015 No. 38864)

[2] E.V. Zarubina, N.A. Loginova, M.M. Novik, Active methods of education, $\mathrm{SPb}$. $-59 \mathrm{p}$.

[3] T.V. Belousova, The use of advanced methods of education in studying process in the customs service universities // The Problems of Modern Science and Education. 2014, no. 2 (20), pp. 107-113.

[4] The Federal Law Enforcement Training - URL: https://www.federallawenforcement.org/training/

[5] BS in Criminology - Online or On-Campus URL:http://landing.criminology.regis.edu/bscrimafutm_source $=x y z \&$ utm_campaign=federallawenforcement\&utm_content=FEATUREDB OX\&utm_term=FEATUREDBOX\&viq_channel=af

[6] Lee Wakefield, Pottathil Akshay, Customs and border security threat recognition training \& technology // Customs Scientific Journal CUSTOMS, no.1, 2014.

[7] Facial recognition is coming to the US airports, fast-tracked by Trump -URL:https://www.theverge.com/2017/4/18/15332742/usborder-biometric-exit-facial-recognition-scanning-homeland-security

[8] Center for Customs and Excise URL:http://www.careercentre.dtwd.wa.gov.au/Occupations/Pages/cus toms-officer.aspx\#tools 
[9] Australian Customs Service: SmartGate Automated Border - URL: https://www.oaic.gov.au/images/documents/migrated/migrated/audre p0702.pdf

[10] Koltsovo Customs Service started the employees' education of profiling -URL: https://otr-online.ru/news/koltsovskaya-tamozhnyanachala-78946.html 